\title{
English Language and Literature: Towards a Model for Implementation of the English/Spanish Bilingual Curriculum in Spain
}

\author{
Jelena Bobkina $^{1} \&$ Elena Domínguez ${ }^{1}$ \\ ${ }^{1}$ Department of English Language and Linguistics, Complutense University of Madrid, Spain \\ Correspondence: Jelena Bobkina, Department of English Language and Linguistics, Complutense University of \\ Madrid, 28040, Madrid, Spain. E-mail: jbobkina@filol.ucm.es
}

Received: September 25, 2014 Accepted: December 2, 2014 Online Published: January 20, 2015

doi:10.5539/elt.v8n2p1 URL: http://dx.doi.org/10.5539/elt.v8n2p1

\begin{abstract}
Bilingual Education is a must in Spain nowadays. Its implementation during the past ten years has involved a meaningful change in teaching methodology. For the first time now our students have the chance to speak and to listen to the target language before they start mastering grammar. As part of this process, English literature is being introduced as an essential element in the bilingual curriculum. Despite the expected initial difficulties that many English teachers have to face in order to work with this new curriculum, no clear reference to possible approaches or materials to be implemented have been provided in any of the existing Decrees so far. It is our intention here to present an integrative approach model for the implementation of literature in the bilingual classroom, thus providing English teachers with a powerful tool to handle literature.
\end{abstract}

Keywords: English/Spanish bilingual curriculum, literature, Spain

\section{Introduction}

Still nowadays, Spain is one of the last European countries to speak a foreign language. More specifically, Ruiz Ocaña (Ruiz-Ocaña, 2014) has recently stated that it is indeed the third country in the EU with the least number of adults ranging 25-54 years who are able to speak at least one foreign language. Quite unexpectedly, though, this is also one of the top European countries in terms of investment on bilingual education. The reason seems to be clear: it will take about 15 years to see the first results, that is to say; for today students to have the time to graduate from university and to join the labour market.

Bilingual education is a relatively recent phenomenon in the Spanish public education system. There is not a unique model for implementation of bilingualism due to the fact that the different regions in Spain enjoy a certain degree of autonomy in terms of education. Nevertheless, it can be said that the Community of Madrid has pioneered the process with the first 26 public bilingual schools starting as far back as 2004. Only private institutions offered this possibility before that time. After ten years, the Bilingual Program in Madrid is now being implemented in about half of the primary schools and a third of the High Schools in the region. The intention is to extend the programme to the upper courses of Secondary Education.

The implementation of the bilingual education has comprised a significant change in the Foreign Language teaching methodology, which has evolved considerably during the past 15 years. For the first time now, Spanish students have the chance to speak and to listen to the target language before actually being forced to master its grammar.

For the sake of clarity and given the prominent role of Madrid in bilingualism, the focus of this study is going to be Spanish/English bilingual secondary education in the Community of Madrid. This is regulated by Decree $3331 / 2010$ of 11 June, which organizes Spanish/English bilingual teaching in secondary schools on the basis of two different modalities: the Bilingual Program and the Bilingual Section. The Decree regulates the teaching of English in each of the two modes and specifies, for the Bilingual Section, that its contents are to be those established in the Advanced English Curriculum which focuses mainly on English language and literature.

The basis for the development of the Advanced English Curriculum for the four courses of Secondary Education in Madrid have been set by the Educational Administration of the Community in the last three years: "The Advanced English Curriculum differs primarily from the Standard Curriculum currently used by English teachers to determine their teaching aims, not only in the extended scope given to the language component, but 
also in the relevance which it gives to the teaching of literature as an essential tool to achieve a competent level of literacy by the end of Compulsory Secondary Education" (Decrees 2154/2010 and 2462-01/2011 and 9961/2012). The following guidelines to better connect English language and literature are provided in each of the three Decrees regulating the Advanced English Curriculum: 1) Define in one given period of time the aims with respect to the target text, 2) Explore the ways literature can be put to use and the different skills that can be worked on, depending on the approach, 3) Set a realistic starting point and reachable reading goals within the Programme aims by assessing students' reading habits and how well they read in their own language, 4) Consider the variables that would make a text more suitable for different aims, and how each option can be exploited as much as possible 5) Consider to what degree collaboration with other colleagues can be achieved so as to better reach goals and enrich the teaching of literature (2154/2010 and 2462-01/2011 and 9961/2012).

It is worth noticing at this point though that no clear reference to possible approaches or materials to be implemented in the Advanced English Curriculum classroom is provided in any of the existing Decrees. No actual model is provided in any of the existing Decrees, which just facilitate some guidelines in a final appendix which advises teachers to use as many teaching resources and as much material as required. The only vague requirement being that "this material, selected by the teachers, should be adjusted to and suitable for said curriculum" (2462-01/2011 and 9961/2012). Deciding which teaching approach is most efficient and most suitable for students of the Advanced English Curriculum is equally up to the teachers though at the same time a factor conditioning the way in which the integration of language and literature is carried about.

These premises posited, the aim of the present study is two-fold: On the one hand, it is our intention to prove that the integrative approach to the teaching of literature meets the demands of the Advanced English Curriculum established in the General Guidelines of the Community of Madrid for years one to four of compulsory secondary education. On the other hand, and in order to achieve this first goal, it is our intention to present an integrative approach model for the implementation of literature in the advanced English language classroom.

Once the aims of the study have been made explicit, the paper is organized as follows: after a general overview of the use of literature in the classroom following this introduction, section 3 analyzes the situation in the Community of Madrid, as regulated by the different Decrees already mentioned. A model for the implementation of the integrative approach to the teaching of English as a combination of language and literature fitting the demands of the advanced English teaching curriculum will be presented in section 4 .

\section{The Use of Literature in the Classroom}

Our interest in the motivational properties of literature in the ESL classrooms is part of a long and animated scholarly conversation, one in which experts have swung between incorporating and abolishing literature as a part of the academic curriculum.

Nowadays, though, research is still being conducted in this field to demonstrate the positive results of using literature in different ESL teaching areas. Thus, Elliott (1990) and De Blasé (2005) describe the successful experience of integrating language and drama activities with literature in a mutually supportive way. Hess (1999) and Hur (2005) depict the multidimensional advantages of literature as a means for developing ESL skills. Meanwhile, McVee et al. (2008) defends the use of poetry as texts with rich potential for multiple interpretations in the language classroom. Also, Bagherkazemi and Alemi (2010) portray the benefits of literary texts as an essential part of integrative language teaching.

When it comes to the actual incorporation of literature into the ESL curriculum, it is worth mentioning that the last century has seen a number of different attempts in this sense (Wellek \& Warren, 1980; Carter \& Long, 1991). Nevertheless, most scholars indicate that none of these approaches is complete enough to be put to practice independently (Maley, 1989; Lima, 2005; Van, 2009). For this reason, a number of integrative models towards teaching English through literature - that include linguistic, cultural and personal elements - have been developed in the last decades (Timucin, 2001; Savvvidou, 2004; Divsar \& Tahriri, 2009).

The above-mentioned approaches are systematically reconciled in the Tasmanian Integrative Model for literature teaching, developed by an Australian group of scholars (Tasmanian Curriculum: Rationale, 2012). As reviewed by Bobkina and Dominguez (2014), in the Tasmanian Model, literary texts are to be approached not only from a linguistic point of view, but also from a social, cultural, and a literary perspective:

1) The Cultural Heritage Perspective supports the view that literature embodies the history, tradition, wisdom and beliefs of a particular society.

2) The Language Skills Perspective considers how students work with texts for reading, writing, listening and speaking skill acquisition. 
3) The Personal Growth Perspective defends the idea that language learning is a holistic, natural process in which meaning is constantly built by students.

4) The Functional Perspective focuses on the analysis of the grammatical structures of language and the identification of the relation existing among, language form, register, and context.

5) The Critical Literacy Perspective supports the view that texts are social constructs reflecting the beliefs and values of their time and culture, with multiple meanings conditioned by the structure of the discourse, the emphases and the omissions (Tasmanian Curriculum: Rationale, 2012).

\section{English Language and Literature Teaching: Problematic Issues in the Advanced English Curriculum in the Community of Madrid}

It has been previously mentioned that the general guidelines for the Advanced English Curriculum-first to fourth year of compulsory secondary education-establish the need to combine language and literature in the teaching of English: "Following this premise, by working towards a command of the language skills (reading, writing, listening and speaking), students will be able to develop their communicative competence and potential, and ultimately increase their ability to function successfully, and actively take part in society" (2154/2010 and 2462-01/2011 and 9961/2012). Nevertheless, the extent to which the teaching of literature and language should be integrated, and "how one hinges on the other", is still considered in each of the three existing Decrees to be an issue to be explored "when deciding which teaching approach is most efficient and most suitable for students of the Advanced English Curriculum" (2154/2010 and 2462-01/2011 and 9961/2012). This means not only that regulations are still in progress with regards to the integration of language and literature, key to the Advanced English Curriculum, but also that particular teaching approaches to be followed are still to be designed.

The lack of accuracy in terms of guidance concerning the use of specific teaching materials is also a fact. While Decree 2154/2010 states that "In conjunction with a conventional workbook (to consolidate grammar and prepare for an external evaluation as established in "Orden 3245/2009, Boletín Oficial de la Comunidad de Madrid"), supplementary materials or anthologies that include reference to the history of literature, movements and authors, can be used as well", later Decrees 2462-01/2011 and 9961/2012 make it clear that these materials are to be selected by the teachers by just making sure to use "as many teaching resources and as much material as required" so to guarantee the implementation of the Curriculum.

Vague regulations pave the way for the exploration in search for new models, approaches and materials allowing teachers in the Community of Madrid to properly implement the new born Advanced English Curriculum. In order to contribute to filling this lack, the following section presents a unit in which the English language is advised to be taught by means of an integrative approach to the teaching of literature. Teaching perspectives like the previously considered Cultural Heritage, Language Skills, Personal Growth, Functional, and Critical Literacy are proved to meet the abovementioned demands of the newly passed Decrees in the Community of Madrid.

With regards to the order of importance in language learning, it is to be said that the supremacy of the acquisition of the skills-reading, writing, listening and speaking-is unquestioned in both the law and the integrative approach. Nevertheless, the development demended of the Advanced English Curriculum students' communicative competence and potential requires the functional analysis of the grammatical structures of language and the identification of the relation existing among language form, register, and context, as observed in the integrative approach. As for the law requirements to increase the students' ability to function successfully and to actively take part in society, it is to be noticed that the cultural heritage and the critical literacy perspectives in the integrative approach go hand in hand. It has been mentioned already that while the first focuses on history, tradition, wisdom and beliefs of a particular society, the second aims at the students' exploration of the historical, cultural and social contexts in which texts are created and interpreted. Needless is to say, the full integrative approach relies as a whole on the students' personal growth for its accurate implementation. 


\section{Integrative Approach to the Advanced English Curriculum in the Community of Madrid: A Model for Implementation in Secondary Education}

Table 1. Pride and prejudice by J. Austin

Jane Austin

Pride and Prejudice

Cultural Heritage Perspective

- Analyze the literary elements of the novel: setting, plot, characters, theme, point of view, narrative voice.

- Intertextuality - explores connections with other Victorian novels.

- Reflect upon the the world of Jane Austen: Describe some of the customs and beliefs of Victorian society.

Language Skills Perspective

- Provide students with meaningful, controlled practice of vocabulary, as well as improve their text-creating and decoding abilities

$\circ$ archaic words

o words with multiple meanings

o descriptive words

o phrasal verbs

o semantic repetitions

- Provide students with meaningful, context-based practice of grammar structures.

o Conditional sentences

$\circ$ Linking words

○ Reported speech

Personal Growth

- Discuss the conveniences/inconveniences of marriage nowadays and in the Victorian times.

- Discuss the relevance of first impressions and their possible impact

Functional Perspective

- Discuss the genre of the novel and the "novel of manners" in particular

- Identify the elements that are being criticized by Jane Austen

Critical Literacy Perspective

- Recognize the importance of the class system in early nineteenth-century England

- Discuss the status of women in early nineteenth-century England

- Organize information in order to evaluate, analyze, and draw conclusions

\section{A Cultural Heritage Perspective}

Learning objectives:

1) To analyze the literary elements of the novel

2) To reflect upon Jane Austen's world

5.1 Focusing on the Literary Elements

\subsubsection{Setting}

Austen sketches the settings of the novel very briefly, leaving it to readers to visualize the places in which the events occur.

Step 1: Working in small groups, students are asked to collect details from the text in order to produce visual representations, such as drawings or models. 
Possible settings:

- Netherfield Park, Bingley's residence

- Pemberley House, Darcy's estate

- The Derbyshire countryside

- Rosings, the home of Lady Catherine

Step 2: Show some clips from a film adaptation of the novel for students to compare their drawings to the representation of the setting in the film.

Discuss:

What are the common details and differences in both of them?

How do the details of setting characterize the people that inhabit them?

\subsubsection{Characterization}

Step 1: Austen doesn't provide too many details of the characters' physical appearances. Most of the characterization is done through their dialogue, thoughts, and actions.

Working in small group students have to build a character sketch based on his/her actions, words, thoughts, etc. They might use the following chart:

\begin{tabular}{|l|l|}
\hline Name of the character \\
\hline What the character says & \\
\hline What the character thinks & \\
\hline What the character does & \\
\hline What other characters say about the character & \\
\hline
\end{tabular}

Step 2: Using the information collected in the previous activity each group should present his/her character.

Characters: Mr. and Mrs. Bennet, Jane, Elizabeth and Lidia Bennet, Mr. Darcy, Miss Darcy, Mr. Bingley, Miss Bingley, Mr. Wickham, Colonel Fitzwilliam, Mr. Collins, Charlotte Lucas, Lady Catherine de Bourgh, Anne de Bourgh.

Step 3: Working in small groups, students analyze the relationships of the following pairs of couples: Jane and Mr. Bingley, Elizabeth and Mr. Darcy, Elizabeth and Wickham, Charlotte Lucas and Mr. Collins, Mr. and Mrs. Bennet, and Lydia and Wickham. Students should collect details from the text to illustrate the relationship of the couple and its development over time.

Step 4: Students work in pairs. They think about one of the characters of this chart and they have to find out the character the other chose by asking yes/no questions using the words or expressions from the previous exercise. (Other words can be also used).

They ask the questions in turns, e.g. 'Is the character a male?' If the answer is affirmative, the students will mark all the female squares in order to know that they are not possible. The following question could be: 'Is he young?'

If the answer is affirmative, he/she will put a mark on Mr. Bennet and Mr. Gardiner squares. Possible solutions at this stage would be Colonel Fitzwilliam, Mr. Collins, Mr. Darcy, Mr. Bingley and Mr. Wickman so the student should still ask some questions in order to guess the character. For instance, a possible question will be: 'is he good looking?' If the answer is negative, the student could only doubt between Colonel Fitzwilliam and Mr. Collins.

$\begin{array}{llll}\text { Mr. Bennet } & \text { Mrs. Gardiner } & \text { Mrs. Bennet } & \text { Jane Bennet } \\ \text { Colonel Fitzwilliam } & \text { Mr. Collins } & \text { Mr. Darcy } & \text { Anne of Bourgh } \\ \text { Miss Bingley } & \text { Lady Catherine of Bourgh } & \text { Charlotte Lucas } & \text { Mr. Gardiner } \\ \text { Lydia Bennet } & \text { Miss Darcey } & \text { Mr. Wickham } & \text { Elizabeth Bennet }\end{array}$

\subsubsection{Tone}

To recognize the tone of the novel is one of the essential skills.

Step 1: For this, students will work with different extracts from the text and will try to analyze their effect on the 
audience. Students should compare the intended meaning of the words with its literal meaning, the effect produced on the characters, and on the readers' understanding of the characters. This might be done orally or in a written form, making notes in their reading journals.

Have a look at Mr. Bennet's reaction to Elizabeth's refusal to marry Collins: "An unhappy alternative is before you, Elizabeth. From this day you must be a stranger to one of your parents-your mother will never see you again if you do not marry Mr. Collins, and I will never see you again if you do".

How can you define Mr. Bennet's tone? How does it reflect the relationship he has with his wife? And with his daughter? What is his attitude towards marriage?

Step 2: Have a look at what Mr. Bennet says to his wife in order to relieve her from her anger after knowing that Charlotte is going to get married to Mr. Collins while it could have been Elizabeth. Mrs. Bennet is upset since Charlotte will take their place at Longbourn after the death of Mr. Bennet.

'Let's hope for better things, my dear', he said. 'Perhaps you may die before me'.

How can you define Mr. Bennet's tone? How does it reflect the relationship he has with his wife?

Step 3: Other possible passages to be discussed:

- Collins' preparation for meeting Lady Catherine.

- The exchange between Lady Catherine and Elizabeth concerning the possibility of an engagement.

\subsection{Jane's Austen World}

A piece of literature embodies the customs and the beliefs of a particular society. In this particular case, Pride and Prejudice depicts the English society of the beginning of the $19^{\text {th }}$ century. This is also called 'Victorian society' since Victoria was reigning Queen of England.

Step 1: Ask students to conduct research on Jane Austen's world, the early $19^{\text {th }}$ century. They might post their findings to a class website, wiki, etc.

In particular, they might work on the following topics:

Social and political situation of England at the early $19^{\text {th }}$ century

The international situation (the Napoleonic Wars, the American revolution, the French Revolution) and its effect on English society.

The elements of popular culture that mark this period (fashion, art, music, dance...)

Step 2: Make a list of evidence to illustrate some of the beliefs or customs of these people according to the novel.

Step 3: The heroine of Pride and Prejudice, Elizabeth Bennet, is said to be inspired on the author, Jane Austen. Look for information on the internet and find some common features between both of them.

\section{A Language Skills Perspective}

Learning objectives:

- Provide students with meaningful, controlled practice of vocabulary, as well as improve their text-creating and decoding abilities

- Provide students with meaningful, context-based practice of grammar structures.

\subsection{Vocabulary Development}

Vocabulary work is intended to be introduced on the discourse level, providing language students with meaningful, controlled practice of vocabulary, as well as giving them a chance to improve their text-creating and decoding abilities in a wide variety of contexts.

\subsubsection{Working with Archaic Words}

Students identify the words in the text that are outdated (time periods: sennight; pastimes: quadrille; whist; vint-et-un).

Later, discuss the modern terms that have replaced these words. Ask students to think why these words have fallen in disuse.

\subsubsection{Working with Multiple Meanings}

Being able to recognize the possibility of a different meaning is an important skill that contributes to a better 
understanding of the text. Students work with the words that are used in the text in a meaning different from the common one.

The following words can be discussed here: mean (5), capital (23), settled (34), approbation (48), wonderful (78), inmate (129), artful (136), want (179-180).

Provide the students with the list of the words to work with and asked them to do the following steps:

- Write the meaning of the word they are familiar with

- Locate it in the passage

- Predict the meaning of the word using co-text and con-text clues

- Look it up in the dictionary and check if you were right.

6.1.3 Working with Descriptive Words

Provide students with the following descriptive words (with the corresponding page numbers) that are used by the author to shed light on particular characters:

fastidious (11) Mr. Darcy; ductility (15) Mr. Bingley; supercilious (17, 19) Mr. Collins; impertinent (22) Mr. Darcy and Elizabeth; pedantic (23) Miss Mary Bennet; insipidity (25) The Bennets (from Miss Bingley's perspective); indolent (33) Mr. Hurst; laconic (57) Mr. Bennet; affability (152) Lady Catherine; condescension (152) Lady Catherine ; obsequiousness (67) Mr. Collins; pompous (61) Mr. Collins; diffidence (251) Miss Darcy; candid (14) Miss Jane; ostentation (14) Miss Jane

Students should identify the word in the text and develop its meaning using the contextual information. Later, this definition is compared with the one from the dictionary.

6.1.4 Working with Phrasal Verbs

Step 1: Work with the following examples from the text. Underline the phrasal verbs and find another verb or expression with the same meaning.

a) They looked down on the country society of Meryton.

b) You will be pleased to hear that I have now made up my mind.

c) I will one day have to take over the home of your respected daughters.

d) I quite look forward to meeting you.

e) My father looked after old Mr. Darcy's property.

f) I was brought up with his son.

g) How is Georgina getting on? (Referring to her piano lessons)

Step 2: Working in pairs, choose two extracts from the text (a narrative passage and a dialogue) analyze the use of phrasal verbs in both of them.

Which of two extracts contains a larger number of the phrasal verbs? Why?

\subsubsection{Semantic Repetitions}

\section{Step 1:}

One of the main themes of the novel is LOVE. In the following activity we will analyze how this feeling is being expressed on the lexical level.

Divide your students in groups and ask them to analyze how the word LOVE is being used throughout the novel. Is it restated in the text by means of direct repetition or by exploiting other lexical relations (synonymy, antonymy, hyponymy/superordinates, collocations).

Each group or pair of students will work with one or two chapters looking for evidences of semantic repetition. Alternatively, a teacher might choose some particular chapters of the novel to work with a whole group.

\section{Step 2:}

Students pick out the most relevant words and phrases from the previous task and try to write what love is for the main character of the novel. 


\subsection{Teaching Grammar in Context}

\subsubsection{Working with Conditional Sentences}

Step 1: Provide students with some uncompleted conditional sentences that have been taken out from the text. Ask them to put the verb in the right tense indicating the type of conditional being used.

Additionally, students can be asked to guess when these sentences were said and by whom.

1) 'If I ........ (know) this morning I wouldn't have called on him'

2) 'If she hides her feelings, she ........ (lose) him.

3) 'If people knew all about the person they were going to marry, they ......... (not do) it.

4) 'If he ......... (continue), I'll let him know what I think'.

5) 'If you refuse Mr. Collins, I ........ never (speak) to you'.

6) 'If I Had known your mother, I ......... (strongly advice) her to get a teacher for you.

7) 'If your feelings ......... (be still) unchanged, just say, ans I'll be silent forever'.

8) If it had been your uncle's doing, I ........ (have to pay) the money back'.

Step 2: Now ask students to have a look at the following sentence in the First Conditional. The choice of 'shall' instead of 'will' is consciously made by the author in order to express something. Ask students to guess why "shall" is used.

'If you accept Mr. Collins, I shan't speak to you' said Mr. Bennet to Elizabeth.

6.2.2 Working with Linking Words

Students will work with the following extract that is taken from Chapter 2. Ask students to introduce the words and expressions from the box without changing the general meaning of the text.

Originally Even Despite the fact that

There was no doubt that How

Richer However Soon

Mr. Bingley was certainly good-looking and very friendly. But his companion, Mr. Darcy, attracted more attention. He was not only better-looking, but also (so people said) had $£ 10,000$ a year. At first people admired him. But then they noticed he was proud. He danced once with each of Bingley's sisters, but showed no interest in any other ladies.

\subsubsection{Working with Reported Speech}

Read the extract from Jane's conversation with his father (Chapter 59). Retell their conversation using indirect speech.

"Or, in other words, you are determined to have him. He is rich, to be sure, and you may have more fine clothes and fine carriages than Jane. But will they make you happy?"

"Have you any other objection," said Elizabeth, "than your belief of my indifference?"

"None at all. We all know him to be a proud, unpleasant sort of man; but this would be nothing if you really liked him."

"I do, I do like him," she replied, with tears in her eyes, "I love him. Indeed he has no improper pride. He is perfectly amiable. You do not know what he really is; then pray do not pain me by speaking of him in such terms."

"Lizzy," said her father, "I have given him my consent. He is the kind of man, indeed, to whom I should never dare refuse anything, which he condescended to ask. I now give it to you, if you are resolved on having him. But let me advise you to think better of it. I know your disposition, Lizzy. I know that you could be neither happy nor respectable, unless you truly esteemed your husband; unless you looked up to him as a superior. Your lively talents would place you in the greatest danger in an unequal marriage. You could scarcely escape discredit and misery. My child, let me not have the grief of seeing you unable to respect your partner in life. You know not what you are about."

\section{A Personal Perspective}

Learning objectives: 
- Discuss the relevance of marriage in the modern society

- Discuss the relevance of first impressions and their possible impact

7.1 The Relevance of Marriage in the Modern Society

Step 1: Charlotte Lucas finally gets married to Mr. Collins. Do you agree with her decision

a. Rank the following values in order of importance according to their influence on Charlotte's decision:

1) The opinion of her family

2) Social Reputation

3) Love

4) Social position

b. Now rank them according to your own views about marriage. You may even add other values in your scale. Justify your choices.

Step 2: Giving special attention to Wickham, Charlotte Lucas, and Elizabeth, compare and contrast male and female attitudes toward marriage in the novel.

Step 3: Discuss the following statement.

Marriage is an outdated institution that no longer reflects modern society

\subsection{The Relevance of First Impressions in the Modern Society}

One of the topics Pride and Prejudice deals with is that of first impressions. Actually, the novel was first intended to be called like that, First Impressions. The novel is concerned with the effects of the character's first impressions which often lead to wrong conclusions. Thus, Elizabeth thinks wrongly about Mr. Darcy and praises Wickham. Although first impressions turn out sometimes not to be fair, we still let them have an influence on us. (The Complete Guide in Teaching Jane Austen, 2010)

Step 1: Ask students if their first impressions are likely to prove accurate or not. Do a quick survey. Count and post the results.

Step 2: Discuss what our first impressions are usually based upon. Make a list and discuss the reliability of the items on the list.

Step 3: Discuss if we ever meet people without prejudging them in some way. Discuss whether it is possible to avoid judging people by their appearance.

Watch the following video of a current daily situation. First, watch only the first 12 seconds in order to do the first part of the exercise.

1) Imagine what each of these people is thinking. What are the old lady's first impressions? And the ones of the man? Can you guess what is it going to happen?

2) Now see the whole video. Did you get surprised with the ending? Why?

\section{A Functional Perspective}

Learning objectives:

- Discuss the genre of the novel and the "novel of manners" in particular

- Identify the elements that are being criticized by Jane Austen

\subsection{The Novel in the $18^{\text {th }} / 19^{\text {th }}$ Centuries}

Jane Austen follows in the footsteps of earlier writers of the novel, a genre which came into popularity in the late 17 th and early 18 th centuries.

Step 1: Discuss with students the names of some other English novelists of the $18^{\text {th }}$ and $19^{\text {th }}$ centuries.

Step 2: Working in small groups, ask your students to create a timeline of the history of the novel, placing Austen and Pride and Prejudice in context. (Posey, 1992)

They might use the following site: http://www.nvcc.edu/home/ataormina/novels/history/default.htm

Step 3: Discuss with students the popularity of poetry and novels at the $19^{\text {th }}$ century:

- Shifting popularity of poetry and fiction. Why one genre is considered more respectable than the other at different points in time? 
- Rising acceptability of female writers. Why, according to family reports, did Austen hide her writing when outsiders entered the room? Why did many female writers, such as the Bronte sisters, use masculine pseudonyms?

\subsection{Satire}

Austen's novels are often referred to as "novels of manners" because she critiques social customs, conventions, and behaviors of a particular social class at a specific time and place.

Step 1: Introduce the concept of satire asking students to talk about any other satirical books they are familiar with.

Step 2: View an extract from The Simpsons and ask students to identify the elements that are being criticized.

Step 3: Students now brainstorm elements of modern society that could be criticized and make their suggestions on how this can be done in fiction. Optionally, they can free write criticizing some aspect of the modern society.

Step 4: Jane Austin's novel is full of different elements criticizing the society of that time.

Ask students to have a look at what Mr. Bennet says to his wife in order to relieve her from her anger after knowing that Charlotte is going to get married to Mr. Collins while it could have been Elizabeth. Mrs. Bennet is upset since Charlotte will take their place at Longbourn after the death of Mr. Bennet.

'Let's hope for better things, my dear', he said. 'Perhaps you may die before me'.

How can you define Mr. Bennet's tone? How does it reflect the relationship he has with his wife?

The other example might be the very first sentence of the novel that sounds rather ironically: "It is a well-known fact that a single man with plenty of money must be in need of a wife."

Step 5: Students work in groups to identify the aspects of the early $19^{\text {th }}$ society that are being criticized in Jane Austen's novel and looking for the excerpts to justify their choice.

\section{A Critical Literacy Perspective}

Learning objectives:

- Recognize the importance of the class system in early nineteenth-century England

- Discuss the status of women in early nineteenth-century England

- Organize information in order to evaluate, analyze, and draw conclusions

\subsection{Jane Austen's Treatment of Social Class in the Early 19th Century}

Jane Austen was a close observer of her society, and one of the characteristics of English society at the early $19^{\text {th }}$ century was the structure of social classes.

Through these activities students will recognize the importance of the class system as presented by Austen in Pride and Prejudice. Working with evidences gathered from the novel, they will analyze the social structure of England in the $19^{\text {th }}$ century.

Step 1: Provide several definitions of the concept of the "class". Discuss it with students. Austen wrote primarily about the upper-middle class. Make sure that students understand its meaning.

Step 2: Before your students begin reading, divide them into small groups and assign each group one of the following relationships to track throughout the novel. They should pay special attention to the class issues that define the relationship between the characters.

Ask students to mark key passages that reflect the importance of class and how it plays out in the lives of the characters.

Jane Bennet and Charles Bingley

Elizabeth Bennet and Fitzwilliam Darcy

Fitzwilliam Darcy and the Gardiners

Lydia Bennet and Lt.Wickham

Mr. Collins and Charlotte Lucas

Mr. Collins and Lady Catherine

Elizabeth Bennet and Lady Catherine 
At the end, each group should identify several passages that best characterize the relationship and prepare a short presentation to comment their findings.

Step 3: Students are asked to construct a social ladder and place all of the characters onto it.

Step 4: Students are asked to discuss Austen's own attitudes toward class, as revealed in Pride and Prejudice.

Possible questions to focus on in the discussion follow:

What does the novel tell us about Austen's attitudes toward the English class system?

It is said that in Pride and Prejudice, Austen satirizes class-consciousness. With the resolution of the novel (the marriages of Jane and Mr. Bingley and Elizabeth and Mr. Darcy) she shows how the power of love and happiness may overcome class boundaries and prejudices. However, she is often criticized as being a classist. Why could this be?

How do you think a reading from a middle-class lady in Austen's times can be different from that of a servant?

\subsection{The Status of Women in England in the Late Eighteenth and Early Nineteenth Centuries}

The novels of Jane Austen offer a close look at the status of women in the early $19^{\text {th }}$ century. Though being often mistaken for peaceful comedies of sheltered lives, in fact, they are sharp dramatizations of the women's situation at that time.

Step 1: One of the central themes of the novel is the role of marriage in the woman's life. In fact, the topic of marriage is introduced already in the first sentence and goes through the whole novel.

Working in groups, students are asked to analyze the attitudes of the female characters towards marriage. To do this, they will have to fill in the following chart.

\begin{tabular}{|l|l|l|}
\hline $\begin{array}{l}\text { List of the female } \\
\text { characters }\end{array}$ & $\begin{array}{l}\text { Brief description (age, class, } \\
\text { education, personality, values) }\end{array}$ & $\begin{array}{l}\text { Her thought towards } \\
\text { marriage }\end{array}$ \\
\hline & & \\
\hline & & \\
\hline
\end{tabular}

Discuss the results. The following questions can be used to guide the discussion:

- What factors were most significant in shaping a character's attitude toward marriage?

- Why were women expected to marry?

- What factors influenced a woman's decision to accept or reject a marriage proposal?

- What were the consequences of a woman's remaining single?

- What do we learn about woman's status in English society from Austen's treatment of marriage in this novel?

Step 2: Pride and Prejudice depicts a society in which a woman's reputation is of the utmost importance. A woman is expected to behave in certain ways.

1) In which ways are women expected to behave in the novel?

2) Do you think women are still expected to behave in certain ways nowadays? Support your opinion with some arguments.

Step 3: One of the historical documents of the early $19^{\text {th }}$ century treating the same topic is Mary Wollstonecraft's treatise, "A Vindication of the Rights of Woman".

Students read some excerpts from Wollstonecraft's document and then compare Austen's and Wollstonecraft's attitude towards the topic.

The following questions can be used to guide the discussion:

- To what extent did Austen and Wollstonecraft agree/disagree in their thinking about the status of women?

- To what extent did Austen and Wollstonecraft agree/disagree on the subject of marriage and the expectations of women/for women in English society?

- Are Wollstonecraft's assertions reinforced by Austen in Pride and Prejudice?

- Does the "Vindication" supply evidence that Austen's depiction of women is realistic? Why or why not? (Posey, 2009) 


\section{References}

Austen, J. (n.d.). The project Gutenberg EBook of Pride and Prejudice. Retrieved March 24, 2014, from http://www.gutenberg.org/files/1342/1342-h/1342-h.htm\#link2HCH0061

Bagherkazemi, M., \& Alemi, M. (2010). Literature in the EFL/ESL classroom: Consensus and controversy. LiBRI. Linguistic and Literary Broad Research and Innovation, 1(1), 1-12.

Brumfit, C. J., \& Carter, R. A. (1986). Literature and Language Teaching. Oxford: Oxford University Press.

Carter, R. A., \& Long, M. N. (1991). Teaching Literature. London: Longman.

Carter, R., Walker, R., \& Brumfit, C. (1989). Literature and the learner: Methodological approaches. Modern English Publications and the British Council.

DeBlase, G. (2005). Teaching Literature and Language through Guided Discovery and Informal Classroom Drama. English Journal, 95(1), 29-32.

Divsar, H., \& Tahriri, A. (2009). Investigating the Effectivness of an Integrated Approach to Teaching Literature in an EFL Context. Pan-Pacific Association of Applied Linguistics, 2(13), 105-116.

Duff, A., \& Maley, A. (1990). Literature. Oxford: Oxford University Press.

Editors, S. (2007). Spark Note on Pride and Prejudice. Retrieved March 24, 2014, from http://www.sparknotes.com/lit/pride/

Elliot, R. (1990). Encouraging Reader-Response in ESL Situations. ELT Journal, 44, 191-198.

Gajdusek, L. (1988). Toward wider use of literature in ESL: Why and how. TESOL Quarterly, 22, 227-254.

Gilroy-Scott, N. (1983). Teaching Literature Overseas: Language-Base Approaches. Oxford: Pergamon Press.

Hess, K. (1999). Poetry as an Intercultural Peace Bridge for Teaching ESL. Alberta: University of Alberta Press.

Hur, H. (2005). Literature-based Activities and Language Socialization in an Elementary ESL Classroom. University Park: The Pennsylvania State University.

Lima, C. (2005). Is the rest silence...? IATEFL, 186. Retrieved from http://www.iatefl.org/iatefl/iatefl-voices.

Llach, P. A. (2007). Teaching language through literature: The waste land in the ESL classroom. Odisea, 8, 7-17.

Maley, A. (1989). Down from the pedestal: Literature as resource. In R. Carter, R. Walker, \& C. Brumfit (Eds.), Literature and the learner: Methodological approaches (pp. 1-9). Modern English Publications and the British Counsel.

McVee, M., Bailey, N., \& Shanahan, L. (2008). Using digital media to interpret poetry: Spiderman meets Walt Whitman. Research in the Teaching of English, 43(2), 112-143.

Orden $n^{\circ}$ 3331. (2010). Por la que se regulan los institutos bilingües de la Comunidad de Madrid. Boletín Oficial de la Comunidad de Madrid.

Orden $n^{\circ}$ 2154. (2010). Por la que se establece el currículo de Inglés Avanzado del primer curso de educación Secundaria Obligatoria para las secciones bilingües de los institutos bilingües de la Comunidad de Madrid. Boletín Oficial de la Comunidad de Madrid.

Orden $n^{\circ}$ 2462. (2011). Por la que se establece el currículo de Inglés Avanzado del segundo curso de la Educación Secundaria Obligatoria para las Secciones Bilingües de los Institutos Bilingües de la Comunidad de Madrid. Boletín Oficial de la Comunidad de Madrid.

Orden $n^{\circ}$ 9961. (2012). Por la que se establece el currículo de Inglés Avanzado del tercero y cuarto cursos de la Educación Secundaria Obligatoria para las Secciones Bilingües de los Institutos Bilingües de la Comunidad de Madrid. Boletín Oficial de la Comunidad de Madrid.

Oster, J. (1989). Seeing with different eyes: Another view of literature in the ESL class. TESOL Quarterly, 23(1), 85-103.

Posey, N. (2009). A Teachers Guide to the Signed Classsic edition of Jane Austen Pride and Prejudice. Retrieved March 24, 2014, from http://www.us.penguingroup.com/static/pdf/teachersguides/PridePrejudice.pdf

Ruiz-Ocaña, J. (2014). La educación bilingue empieza a dar sus frutos en España. Retrivied September 25, 2014, from http://www.expansion.com/2014/01/30/entorno/1391091142.html

Savvidou, C. (2004). An integrated approach to the teaching of literature in the EFL classroom. The Internet TESL Journal, 12. 
Stern, S. (1985). Teaching Literature in ESL/EFL: An Integrative Approach. Los Angeles: University of California.

Tasmanian Curriculum: Rationale. (2012). Retrieved March 24, 2014, from www.education.tas.gov.au/ curriculum/standards/english/english/teachers/rationale

The Complete Guide to Teaching Jane Austen. (2010). Retrieved March 24, 2014, from http://www-tc.pbs.org/ $\mathrm{wgbh} /$ masterpiece/austen/austen_teachersguide.pdf

Timucin, M. (2001). Gaining insight into alternative teaching approaches employed in an EFL literature class. Revista de Filología y su Didáctica, 24, 269-293.

Topping, D. M. (1968). Linguistics or literature: An approach to language. TESOL Quarterly, 2(2), 95-100.

Van, T. (2009). The relevance of literary analysis to teaching literature in the EFL classroom. English Teaching Forum, 2(9), 3.

Wallek, R., \& Warren, A. (1984). Theory of Literature. New York: Mariner Books.

\section{Copyrights}

Copyright for this article is retained by the author(s), with first publication rights granted to the journal.

This is an open-access article distributed under the terms and conditions of the Creative Commons Attribution license (http://creativecommons.org/licenses/by/3.0/). 